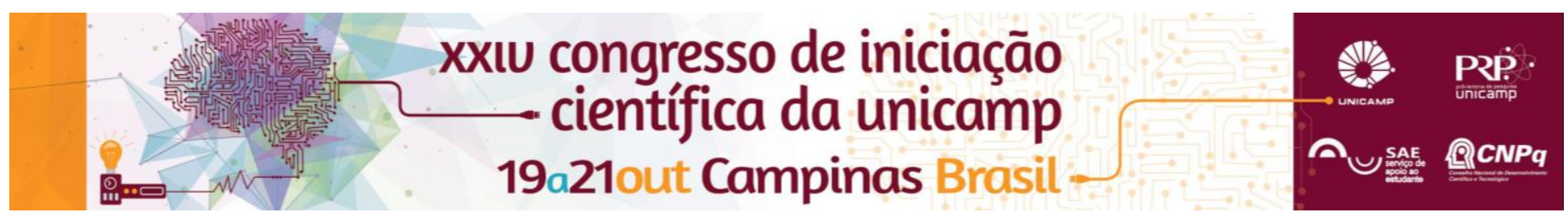

\title{
O Atlântico Sul e a sua importância estratégica para o Brasil como potência hemisférica.
}

\author{
Lucas de Toledo Amici*, Claudete de Castro Silva Vitte.
}

\begin{abstract}
Resumo
Esta pesquisa estudou o desafios enfrentados pelo Brasil para assumir o controle do Atlântico Sul. Para a sua realização, combinou-se bibliografias da geografia e das relações internacionais, especialmente aquelas que tratassem do tema do território e das relações estatais, aos dados encontrados em órgãos especializados e trabalhos recentes na área. A partir disso, verificou-se um aumento significativo na importância deste oceano, sobretudo após a descoberta do pré-sal, podendo-se concluir que este empreendimento será o principal mecanismo brasileiro para estimular uma hegemonia na região sul-atlântica.
\end{abstract}

\section{Palavras-chave:}

Brasil, Atlântico Sul, Geopolítica.

\section{Introdução}

A consolidação geopolítica chinesa somada a crise econômica de longa duração que atinge a Europa vem causando diversos impactos no eixo econômico mundial, que se desloca cada vez mais para o oceano Pacífico. A iminente retirada dos Estados Unidos, principal agente hegemônico global, do oceano Atlântico para o oceano Pacífico, abre vazios para que novas potências regionais tomem o seu lugar no controle e na atuação dessa região marinha.

A área correspondente ao Atlântico Sul, circunscrita essencialmente por países chamados periféricos, que abrange os continentes da América do Sul (na sua porção leste) e da África (oeste), mostra-se proeminente para o Brasil na criação de um protagonismo.

Portanto, o objetivo dessa pesquisa foi entender as principais implicações estratégicas para o Brasil na tentativa de assumir o controle político e econômico do Atlântico Sul, identificando a sua importância políticoeconômica, particularmente após o descobrimento do pré-sal, e traçar os principais obstáculos e caminhos brasileiros para a criação de uma hegemonia.

\section{Resultados e Discussão}

Para a elaboração desta pesquisa, realizou-se uma revisão bibliográfica e a análise de conteúdo de trabalhos recentes de Brasil, Argentina e os países africanos, a partir de diversas fontes, tais como documentos de órgãos de segurança dos governos, jornais, agências especializadas e pesquisas recentes na área.

A marinha brasileira expande as fronteiras da soberania nacional não somente por motivos econômicos, mas também por propósitos estratégicos e de exclusividade, como indicado por Mearsheimer: "para que a marinha domine um oceano, não precisa controlar sempre todo o mar, mas tem que ser capaz de controlar as zonas estrategicamente importantes sempre que deseje utilizálas e negar ao inimigo a capacidade de o fazer" (MEARSHEIMER, 1997, p. 96) ${ }^{1}$.

Os números mostram que a produção de petróleo no Brasil cresce exponencialmente, muito em função da descoberta do pré-sal, indicando uma importância econômica e geopolítica do Atlântico Sul para o país, como pode ser visto no gráfico 1 .
Gráfico 1. Produção de petróleo no Brasil (em milhares de barris diários) e participação (em \%) sobre a produção mundial, 2004-2014²

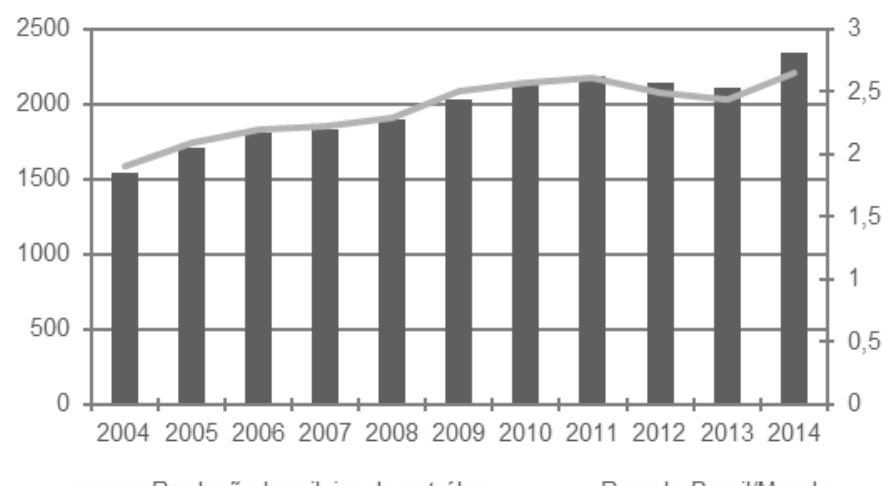

\section{Conclusões}

A importância geopolítica do Atlântico Sul expressa-se de várias maneiras, o que necessita de uma nova visão do território nacional, onde o oceano venha a ter um papel central na defesa e no uso de recursos, possibilitando um desenho do território sob comando estatal.

A relação entre o mercado e a expansão da fronteira marítima se torna evidente em virtude da dependência nas relações da geopolítica, que acaba exigir formas de defesa que garantam a sua exploração - explorar reivindica o avanço territorial.

O domínio do Atlântico Sul pelo Brasil coloca o país em uma situação privilegiada com relação ao hemisfério sul, com o estreitamento de relações bilaterais com países africanos, com o propósito de futuramente criar uma identidade sul-atlântica.

\section{Agradecimentos}

Agradeço a concessão da Bolsa PIBIC/CNPq e a todos que me ajudaram nesse projeto.

${ }^{1}$ MEARSHEIMER, John J. A tragédia da política das grandes potências Lisboa: Gradiva, 2007.

2 Elaboração própria a partir dos dados: de BP Statistical Review of World Energy (2015). Disponível em: https://www.bp.com/content/dam/bp/pdf /energy-economics/statistical-review-2015/bp-statistical-review-of-world-energ y-2015-full-report.pdf. Acesso em: jun. 2016. 